to enable him to visit the Rowett Research Institute, Aberdeenshire, and elsewhere in the United Kingdom in order to extend his knowledge of the chemistry and structure of plant proteins and peptides; Dr. C. K. Job, associate professor of pathology, Christian Medical College, Vellore, South India, to assist him to study modern techniques in experimental pathology at University College Hospital Medical School, London; Dr. T. Langford-Smith, senior lecturer in physical geography, University of Sydney, to enable him to study pleistocene stream traces in Kenya (and western United States) as a guide to pleistocene pluvial changes, and to study soil development in loess from selected sites in the United Kingdom; Dr. P. B. C. Matthews, university lecturer in physiology, Oxford, to assist him to gain experience of neurophysiological techniques and their application to the study of the central nervous system and to advance knowledge of cerebellar function, at the Australian National University, Canberra; Dr. D. F. Mettrick, lecturer in zoology, University of West Indies, Kingston, Jamaica, to assist him to study new techniques in experimental parasitology at the University of Glasgow; Dr. R. L. Specht, reader in ecology, University of Melbourne, to enable him to visit Oxford in order to study recent techniques developed there for investigation of the phosphorus nutrition and growth of heath communities on infertile soils; Dr. D. R. Westbrook, lecturer in mathematics, University of Singapore, to enable him to gain contact with other mathematicians working in the field of the theory of elasticity, at Melbourne; Dr. A. Wright, lecturer in veterinary anatomy, University of Sydney, to assist him to visit the University of Hong Kong in order to develop techniques for surgery on birds and to conduct a collaborative research project on the effect of hormones on avian kidney function.

\section{The Pharmaceutical Society of Great Britain: Awards}

THE Pharmaceutical Society of Great Britain has instituted two new awards which will be known respectively as the Charter Gold Medal and the Charter Silver Medal. The Charter Gold Medal will recognize the outstanding service rendered by the member to the Society, or generally in promoting the interests of pharmacy. The Charter Silver Medal will recognize similar outstanding service rendered by the member locally.

Charter Gold Medals for $\mathbf{1 9 6 4}$ have been awarded to: W. S. Howells, who was vice-president of the Society in 1941-42, president from 1942 until 1944, and treasurer from 1947 until 1963; Dr. T. E. Wallis, emeritus curator of the Pharmaceutical Society's Museum. A Charter Silver Medal has been awarded to H. R. Edgecombe, who has been prominently associated with local pharmaceutical organization since 1934, having served as president and as secretary of the South-West London Chemists' Association for more than twenty years.

\section{Postgraduate Awards in Agricultural Research}

A воокLeт, which is entitled Postgraduate Studentships and Fellowships offered in 1964, and issued by the Agricultural Research Council, details the postgraduate research studentships and fellowships to be offered in 1964 by the Agricultural Research Council (Pp. 23. London: Agricultural Research Council, 1964). The Council offers thirty postgraduate studentships in Agricultural Research. including veterinary training grants; the closing date for applications is March 16. Two veterinary research fellowships, tenable for a period of up to three years, are offered to workers holding a veterinary qualification and with at least three years' experience in veterinary research, and three agricultural research fellowships, also tenable for a period of up to three years, will be open to honours graduates in science with not less than three years' postgraduate experience. Applications for these awards can be made at any time. Candidates for the postgraduate studentships and research fellowships must be
British subjects. The booklet also eontains sections on: the scope of agricultural research; the openings available in agricultural research and advisory research; regulations governing awards; analysis of subsequent appointment of holders. Two appendixes deal with: (1) State-aided agricultural institutes and Agricultural Research Council institutes and units; (2) Scottish Agricultural Advisory Service: agricultural colleges.

\section{Announcements}

H.R.H. Prince Philip, Duke of Edinburgh, has agreed to become patron of the Ian Clunies Ross Memorial Foundation. The Foundation was established in 1959 in memory of the former chairman of the Commonwealth Scientific and Industrial Research Organization, Australia. An initial objective is to build a national science centre near the University of Melbourne; already more than £A280,000 has been raised towards this project.

Prof. R. G. D. Alluen, professor of statistics in the University of London since 1944, has been appointed a member of the Council for Scientific and Industrial Research. Prof. Allen was at one time statistical adviser to H.M. Treasury and a consultant to the United Nations Statistical Office. He has been a part-time member of the Air Transport Licensing Board since 1960; he is also chairman of the Committee set up in 1963 by the Minister of Housing and Local Government to examine the impact of rates on different sections of the community, and is treasurer of the British Academy.

A CONFERENCE on "Finishes for Reinforced Plastics". organized by the Reinforced Plastics Group of the Plastics Institute, will be held in Birmingham on February 20. Further information can be obtained from the Plastics Institute, 6 Mandeville Place, London, W.1.

A CONFERENCE on "Dielectric and Insulating Materials". arranged by the Institution of Electrical Engineers, will be held in London during April 8-10. Further information can be obtained from the Secretary, Institution of Electrical Engineers, Savoy Place, London, W.C.2.

A symposium on "Ecology and the Industrial Society". arranged by the British Ecological Society, will be held at the University College of Swansea during April 13-16. Further information can be obtained from Mr. G. T. Goodman, Department of Botany, University College. Singleton Park, Swansea.

A meeting on "Chemotherapy of Tropical Diseases: Amœbiasis, Helminthiasis, Trypanosomiasis", arranged by the Fine Chemicals Group and the Nottingham Section of the Society of Chemical Industry, will be held in Nottingham during April 6-7. Further information can be obtained from Mr. F. E. Rymill, Allen and Hanburys. Ltd., Ware, Herts.

A meeting, which is being organized by the Société de Chimie Biologique to celebrate its fiftieth anniversary, will be held in Paris during April 6-9. Subjects under discussion will include: the chemistry of heredity; biochemistry of antigens; mechanisms of enzymatic action; transfer of energy. Further information can be obtained from La Société de Chimie Biologique, 4 avenue de l'Observatoire, Paris 6.

THE third international symposium on "Fleming"s Lysozyme" will be held in Milan during April 3-5. Subjects under discussion will include: biology of lysozyme; lysozyme and lysozyme-like substances; lysozyme action against viruses, bacteria and protozoa; therapeutic use of lysozyme in general medicine, surgery, pædiatries. oculistics, neurology, phthisiology, dermatology, gynæcology, urology, oto-rhino-laryngology, odontostomato logy. Further information can be obtained from Prof. G. Podio, c/o "A. Fleming" Institute, Via Modica 6, Milan. 